\title{
Video-based flipped learning in higher education: Effects on students' learning motivation, attitudes, and engagement
}

\author{
Mariam Haghegh ${ }^{1}$ (1) https://orcid.org/0000-0003-0647-9430 \\ Arif Nugroho $^{2^{*}}$ (1) https://orcid.org/0000-0001-9805-9948 \\ ${ }^{1}$ Faculty of Education, Eastern Mediterranean University, North Cyprus Turkey \\ 2 UIN Raden Mas Said Surakarta, Indonesia
}

\begin{abstract}
In the recent years, flipped learning has become popular and been widely utilized as teaching approach to activate students' learning engagement, which is frequently used to reverse the conventional teaching. However, much more efforts are necessary to enrich the literature about its practices across different teaching and learning contexts. This study is at the cutting edge of examining the practice of flipped learning in higher education contexts; as well as exploring its effects on students' learning motivation, attitudes, and engagement. Data were collected using a questionnaire from 35 undergraduate students enrolled in "Introduction of Educational Technology" course at a college of education, and the data were tested using 24-version IBM-SPSS linear regression. The results demonstrated that flipped learning strategy is a positive predictor for students' learning motivation ( $p$-value $0.001<0.05$ ), attitudes ( $p$-value $0.007<0.05$ ), and engagement ( $p$-value $0.003<$ 0.05). The results contribute to offering valuable insights for college stakeholders to enhance the efficacy of teaching and learning process, particularly for higher education curriculum designers to adapt to the current teaching approach. Instructional implication and research suggestions are provided based on the results of the study.
\end{abstract}

\section{ARTICLE INFO \\ Keywords:}

flipped learning; learning attitude; learning motivation; learning engagement

\section{Article History:}

Received: 01 November 2021

Revised: 13 December 2021

Accepted: 29 December 2021

Published: 30 December 2021

\section{How to Cite in APA Style:}

Haghegh, M., \& Nugroho, A. (2021). Video-based flipped learning in higher education: Effects on students' motivation, attitudes, and engagement. Journal of Educational Management and Instruction, 1(2), 92-101.

\section{Introduction}

Flipped learning approach has recently attracted much attention worldwide, and has become more popular and widely adopted in today's classroom learning. It transforms into an alternative pedagogical approach concerning on collaborative and student-centered learning activities that offers in-class and out-class instruction to reverse the traditional classroom environment (Ginola \& Sidabalok, 2016; Singay, 2020.). The fundamental idea of flipped learning is to introduce students to course materials prior the classroom so that they can comprehend the materials at a deeper level in the classroom (Bergmann \& Sams, 2012). Strayer (2012) posits that the systematic use of technology plays a crucial role in assisting the practice of flipped learning activities. Interactive technology tools such as Google classroom, social media, and LMS are a promising platforms that can be used to facilitate flipped learning because they provide not only platforms to collecting students' responses, but also support stronger communication, sharing, and socializing (Ginola \& Sidabalok, 2016; Haghighi et al., 2019; Young et al., 2014).

Previous studies have examined the effects of flipped learning on enhancing the efficacy of teaching process. Flipped learning activities should be designed to foster the ability of learners to construct meaningful personal knowledge and to cultivate a higher level of cognitive skills such as analyzing, applying, and evaluating (Coley et al., 2013), 
higher order thinking skills (Hwang et al., 2015; Hwang et al., 2019; Suprapti et al., 2021), and communicative competence (Ginola \& Sidabalok, 2016; Makruf et al., 2021). It has also been proven as an effective approach to enhance students' performance and achievement across fields of study such as mathematics (Lo \& Hew, 2020), physical therapy (Chung \& Lee, 2018), physical education (Hinojo Lucena et al., 2020), algorithms and programming education (Karaca \& Ocak, 2017), and foreign language (Lee \& Wallace, 2018).

Learning task-based technology incorporated in higher education teaching might improve students' motivation and engagement, and consequently increase their attitude toward learning. This study is based on the assumption that if university students possess more opportunities to be actively involved in a flipped learning design activity, they may willingly engage in deep thinking and active discussion during classroom activities, and they will show good attitudes toward learning. As mentioned by Zhang et al. (2020), there are only a few pedagogical approaches that can foster the students' engagement and performance toward learning. Solution to this issue requires a concept and understanding about appropriate teaching method in the context of higher education. Flipped learning strategy, by referring to the previous studies elicited above, can be a promising alternative approach to enhance students' learning motivation, attitudes, and engagement. Therefore, this study creates an innovative flipped learning instructional design in "Introduction to Educational Technology" class by incorporating flipped learning approach and examining its effects on students' learning motivation, attitudes, and engagement. A questionnaire adapted from previous studies (Pierce et al., 2012, Chang et al., 2016; Lin \& Chen, 2016, Lai \& Wu, 2006; Wei et al., 2016, and Hung, 2015) was developed to examine the effectiveness of the approach, using linear regression by means of 24-version IBM-SPSS.

\section{Flipped learning}

In the recent years, flipped learning design for classroom instruction becomes popular and has drawn experts' attention. The idea of flipped learning was firstly coming up when Bergmann and Sams (2012) looked for an effective teaching method for the absent students to have an access on the class lessons and materials. They recorded the lessons and made use of a digital platform to post the recordings online so that the students who did not join the class still be able to follow the learning materials by watching the videos at any time and any place. Then, they found out that the model of learning greatly helped students who could not attend the class. Surprisingly, the students who attended the class could also watch the videos and this activity helped them review and revisit the day's lessons. It initiates the concept of massive integration of digital technology in the process of teaching and learning called flipped learning instruction (Bergmann \& Sams, 2012; Chen et al., 2014).

The unique procedure of flipped learning approach comprises pre-class learning activity and in-class learning activity. In the context of our learning system, it reverses the role of home-assignments and classroom activities, where students engage in several activities prior to the class and in the class. In pre-class tasks, they can perform learning activities such as brainstorming about materials and tasks, viewing instructional videos, and listing inquiries or questions. Meanwhile in the classroom, they are directed to be more active in presentation, collaborative work, discussion, or project-based activities (Chen Hsieh et al., 2017). Using the word "FLIP", the key concept of flipped learning strategy is being a flexible learning environment, where collaboration, problem-based, and student-centered activities are pivotal in the learning process (Heo \& Chun, 2018; Jamaludin \& Osman, 2014; Wahyuningsih \& Baidi, 2021). Katchamat (2018) points out that flipped learning is alternative to conventional teaching, requiring instructors to possess professional knowledge and skills on designing the pre-class and in-class activities. 


\section{The study}

Although previous studies have revealed the effectiveness of flipped learning in teaching and learning pedagogy, much more efforts are to be done to enrich the literature about its practices across different teaching and learning contexts. It is in line with the concept of twenty-first teaching and learning, in which digital literacy becomes the main focus. This study is based on a conceptual framework that if students are actively involved in a flipped learning activity design, they might be acquire high level of motivation, attitudes, and engagement toward learning. It is due to the fact that the present-day students were born as digital natives who are familiar with the use of technology in day-to-day interaction. Drawing on this issue, the in-hand study aims to examine the effects of flipped learning strategy on higher students' learning motivation, attitudes, and engagement toward the learning process. This study recruits 35 undergraduate students enrolled in "Introduction to Educational Technology" course at a college of education. The results contribute to offering valuable insights for college stakeholders to enhance the efficacy of teaching and learning process, particularly for higher education curriculum designers to adapt to the current teaching approach. For teachers and instructors, this study becomes a reference in designing technology-based learning activities.

Compared to conventional teaching method, flipped learning strategy has been reported to have positive effects on learning motivation (Chao et al., 2015; Chen et al., 2014; Davies et al., 2013; Makruf et al., 2021; Strayer, 2012) and student engagement (Bergmann \& Sams, 2012; Gilboy et al., 2015; Suprapti et al., 2021; Webb \& Doman, 2020). By the empirical evidence from the previous results, exploring the potential effect of flipped learning method on higher education students' motivation, attitudes, and engagement becomes an interesting attribute to explore. Therefore, following the previous studies, this study postulates the below hypotheses:

H1: Flipped learning strategy has a positive effect on students' learning motivation H2: Flipped learning strategy has a positive effect on students' learning attitudes H3: Flipped learning strategy has a positive effect on students' learning engagement

\section{Method}

\section{Research context}

This research was primarily conducted in a compulsory subject at the College of Education, particularly in "Introduction to Educational Technology" course. The class members consisted of 35 third-year students. They were taught under the procedure of flipped learning in eight meetings during the end of 2020. First of all, the students were divided into several groups in five to seven of each. The design of flipped learning in this study comprised pre-class learning and in-class learning (see Table 1). In pre-class learning, students were assigned to watch instructional videos related the upcoming topic, and all students were required to complete pre-class reading material. Moreover, each group was asked to create a summary of the instructional video and the textreading materials, as well as list of questions related to the material (if any). During the in-class learning activity, each group presented a report to offer details and comprehensive discussion about a course topic. Other groups generated their issues and questions, and they have question-answer section among the students. The instructor facilitated and helped to guide students in the class discussion. Later, other students attempted to answer questions arisen in the class discussion based on their understanding of the topic and material, and the instructor explored and elaborated upon the learning contents after the class discussion when necessary. 
Table 1. Weekly Course Activities

\begin{tabular}{lll}
\hline Activity type & Activity \\
\hline $\begin{array}{l}\text { Pre-class } \\
\text { learning }\end{array}$ & - & $\begin{array}{l}\text { Students read and identify the topic and material of upcoming } \\
\text { meeting and watch instructional videos given by the } \\
\text { instructor }\end{array}$ \\
& - $\begin{array}{l}\text { Students create summary and question lists related to the } \\
\text { material. }\end{array}$ \\
\hline $\begin{array}{l}\text { In-classroom } \\
\text { learning }\end{array}$ & - $\begin{array}{l}\text { A group made an oral presentation (about } 30 \text { min) related to a } \\
\text { course topic and instructional video }\end{array}$ \\
& - $\begin{array}{l}\text { Each group generated their questions } \\
\text { A discussion focusing on questions that the students } \\
\text { generated. } \\
\text { The team presentation attempted to answer the others' } \\
\text { questions, and other students could express their opinions. } \\
\text { Teacher feedback, elaborating the different concepts and } \\
\text { clarifying misconceptions, and giving addition explanation }\end{array}$ \\
\hline
\end{tabular}

\section{Participants}

The participants in this study were 35 undergraduate students from the college of education. There were 21 females (60\%) and 14 males (40\%), and the majority (90\%) of the participants were between 20 and 22 years old. A consent was firstly obtained from each participant before collecting the data. Convenience sampling was used in this research.

\section{Instrument and data collection}

A questionnaire adapted from previous studies related to variables in this research was used. The questionnaire was intended to examine students' motivation, attitudes, and engagement toward learning under the procedure of flipped learning strategy. The questionnaire consisted of 16 items to evaluate 4 constructs, including flipped learning strategy (Pierce et al., 2012), students' learning motivation (Chang et al., 2016; Lin \& Chen, 2016), attitudes (Lai \& Wu, 2006; Wei et al., 2016), and engagement (Hung, 2015) (see table 2). Each statement was measured on a five-point Likert scale, with 1 point indicating "strongly disagree" to 5 points indicating "strongly agree". The questionnaire was distributed to the participants after they experienced in eight-meeting lessons using flipped learning method during the course.

Table 2. Questionnaire Items

\begin{tabular}{|c|c|c|c|}
\hline Construct & Item & Description & Reference \\
\hline \multirow{4}{*}{$\begin{array}{l}\text { Flipped } \\
\text { learning } \\
\text { strategy }\end{array}$} & FL1 & $\begin{array}{l}\text { I learned more from flipping, and I prefer the } \\
\text { flipped class over conventional teaching }\end{array}$ & \multirow[t]{4}{*}{$\begin{array}{l}\text { Pierce et } \\
\text { al. (2012) }\end{array}$} \\
\hline & FL2 & $\begin{array}{l}\text { I learned more by collaborating with others } \\
\text { by sharing and commenting }\end{array}$ & \\
\hline & FL3 & $\begin{array}{l}\text { Flipped learning has reduced my dependency } \\
\text { on the lecturer }\end{array}$ & \\
\hline & FL4 & $\begin{array}{l}\text { Flipped learning classroom has helped my } \\
\text { personal development }\end{array}$ & \\
\hline \multirow{5}{*}{$\begin{array}{l}\text { Learning } \\
\text { motivation }\end{array}$} & LM1 & I like the way the class is being taught & Chang et \\
\hline & LM2 & The way the class is taught draws my & al., 2016; \\
\hline & LM3 & attention & Lin \& \\
\hline & & I have more understanding of the process & Chen, \\
\hline & LM4 & involved in this learning activity & 2016 \\
\hline
\end{tabular}

Mariam Haghegh, Arif Nugroho. Video-based flipped learning in higher education: Effects on students' learning motivation, attitudes, and engagement 


\begin{tabular}{|c|c|c|c|}
\hline Construct & Item & Description & Reference \\
\hline & & $\begin{array}{l}\text { I like the strengthening activity that helps me } \\
\text { learn about the process related to educational } \\
\text { technology topic }\end{array}$ & \\
\hline $\begin{array}{l}\text { Learning } \\
\text { attitudes }\end{array}$ & $\begin{array}{l}\text { LA1 } \\
\text { LA2 } \\
\text { LA3 } \\
\text { LA4 }\end{array}$ & $\begin{array}{l}\text { I had to work harder in this course } \\
\text { Overall, I like learning in this course } \\
\text { I have more understanding of the process } \\
\text { involved in this course } \\
\text { I had sufficient ability to learn and } \\
\text { comprehend the course materials }\end{array}$ & $\begin{array}{l}\text { Lai \& Wu, } \\
\text { 2006; Wei } \\
\text { et al., } 2016\end{array}$ \\
\hline $\begin{array}{l}\text { Learning } \\
\text { engagement }\end{array}$ & $\begin{array}{l}\text { LE1 } \\
\text { LE2 }\end{array}$ & $\begin{array}{l}\text { I am willing to spend more time to learn this } \\
\text { course } \\
\text { I will keep my mind on listening to and } \\
\text { looking at my teacher's or other students' } \\
\text { explanation and demonstration } \\
\text { I will answer the teacher's or other students' } \\
\text { questions on my own initiative when } \\
\text { participating in this course } \\
\text { I can use my own initiative to collect the } \\
\text { materials about this course content }\end{array}$ & $\begin{array}{l}\text { Hung, } \\
2015\end{array}$ \\
\hline
\end{tabular}

\section{Data analysis}

Data were collected on students' responses toward flipped learning strategy, learning motivation, attitudes, and engagement, all measured by the self-reported questionnaire. Students completed the questionnaire individually in Google form platform to assist the process of data tabulation. This study employed simple linear regression using 24-version of IBM-SPSS to analyze the data obtained from the questionnaire. The hypotheses statements were tested, and the relationship between flipped learning strategy and students' learning motivation, attitudes, and engagement was examined. In this study, p-value threshold for statistical significance was set at .05. The validity of the instruments was checked and resulted in all Pearson correlation values were positive, meaning that all items were valid. Furthermore, its reliability was also examined using Cronbach's alpha, and all items had alpha value exceeding the threshold 0.6, indicating that all items were reliable.

\section{Results}

\section{Effect of flipped learning on students' learning motivation}

The first hypothesis of this study states that flipped learning strategy has an influence on students' learning motivation. To seek the empirical answer of the hypothesis, simple liner regression was conducted by means of 24-version of IBM-SPSS. Table 3 presents the result of analysis. It is found that the significant value of the first hypothesis testing is $0.001(<0.05)$, meaning that flipped learning strategy has an influence on the students' learning motivation.

Table 3. First Hypothesis Testing Result

\begin{tabular}{llccccc}
\hline \multirow{2}{*}{ Model } & \multicolumn{2}{c}{$\begin{array}{c}\text { Unstandardized } \\
\text { Coefficients }\end{array}$} & $\begin{array}{c}\text { Standardized } \\
\text { Coefficients }\end{array}$ & t & \multirow{2}{*}{ Sig. } \\
\cline { 2 - 5 } & $\mathbf{B}$ & Std. Error & Beta & & \\
\hline 1 & (Constant) & 23.285 & .918 & & 25.366 & .000 \\
& $\begin{array}{l}\text { Flipped } \\
\text { learning }\end{array}$ & .298 & .043 & .411 & 6.881 & .001 \\
\hline
\end{tabular}

a. Dependent Variable: Students' Learning Motivation 
Moreover, to see the level of influence, it could be seen in the model summary analysis (R-square) using 24-version of IBM-SPSS. Table 4 depicts that the R-square value is 0.661 , meaning that flipped learning strategy gives an influence of $66.1 \%$ on students' learning motivation, while the rest was affected by other variables excluded in this study.

Table 4. Model Summary (R-square)

\begin{tabular}{ccccc}
\hline Model & $\mathbf{R}$ & R-square & $\begin{array}{c}\text { Adjusted } \mathbf{R} \\
\text { square }\end{array}$ & $\begin{array}{c}\text { Std. Error of } \\
\text { the Estimate }\end{array}$ \\
\hline 1 & $.813^{\mathrm{a}}$ & .661 & .627 & 1.40170 \\
\hline
\end{tabular}

a. Predictors: (Constant), Flipped learning

\section{Effect of flipped learning on students' learning attitudes}

The second hypothesis of this study states that flipped learning strategy has an influence on students' learning attitudes. Table 5 demonstrates that the significant value of the second hypothesis testing result is $0.007(<0.05)$, indicating that flipped learning strategy shares an influence on students' learning attitudes.

Table 5. Second Hypothesis Testing Result

\begin{tabular}{llccccc}
\hline \multirow{2}{*}{ Model } & \multicolumn{2}{c}{$\begin{array}{c}\text { Unstandardized } \\
\text { Coefficients }\end{array}$} & $\begin{array}{c}\text { Standardized } \\
\text { Coefficients }\end{array}$ & t & \multirow{2}{*}{ Sig. } \\
\cline { 2 - 4 } & $\mathbf{B}$ & Std. Error & Beta & & \\
\hline 2 & (Constant) & 31.834 & 1.021 & & 25.634 & .000 \\
& $\begin{array}{l}\text { Flipped } \\
\text { learning }\end{array}$ & .211 & .032 & .932 & 3.811 & .007 \\
\hline
\end{tabular}

b. Dependent Variable: Students' Learning Attitudes

In addition, the R-square value shown in table 6 is 0.714 , which means flipped learning strategy influences the students' learning attitudes as many as $71.4 \%$, while the rest was affected by other variables which were not included in this study.

Table 6. Model summary (R-square)

\begin{tabular}{ccccc}
\hline Model & $\mathbf{R}$ & R-square & $\begin{array}{c}\text { Adjusted R } \\
\text { square }\end{array}$ & $\begin{array}{c}\text { Std. Error of } \\
\text { the Estimate }\end{array}$ \\
\hline 2 & $.973^{\mathrm{a}}$ & .714 & .636 & .90153 \\
\hline
\end{tabular}

a. Predictors: (Constant), Flipped learning

\section{Effect of flipped learning on students' learning engagement}

The third hypothesis of this study states that flipped learning strategy has an influence on students' learning engagement. The result of simple linear regression presents that the significant value of the third hypothesis is $0.003(<0.05)$, which suggests that the hypothesis is accepted. It concludes that flipped learning strategy affects the students' learning engagement.

Table 7. Third Hypothesis Testing Result

\begin{tabular}{llccccc}
\hline \multirow{2}{*}{ Model } & \multicolumn{2}{c}{$\begin{array}{c}\text { Unstandardized } \\
\text { Coefficients }\end{array}$} & $\begin{array}{c}\text { Standardized } \\
\text { Coefficients }\end{array}$ & \multirow{2}{*}{ t } & \multirow{2}{*}{ Sig. } \\
\cline { 2 - 4 } & $\mathbf{B}$ & Std. Error & Beta & & \\
\hline 3 & $\begin{array}{l}\text { (Constant) } \\
\text { Flipped }\end{array}$ & 27.543 & 1.322 & & 26.214 & .000 \\
& .432 & .975 & .762 & 4.345 & .003 \\
\hline
\end{tabular}

c. Dependent Variable: Students' Learning Engagement 
Furthermore, the R-square value of the third hypothesis is 0.681 , which implies that flipped learning strategy shares its $68.1 \%$ influence on the students' learning engagement, while the rest was influenced by other variables excluded in this study.

Table 8. Model Summary (R-square)

\begin{tabular}{ccccc}
\hline Model & $\mathbf{R}$ & R-square & $\begin{array}{c}\text { Adjusted } \mathbf{R} \\
\text { square }\end{array}$ & $\begin{array}{c}\text { Std. Error of } \\
\text { the Estimate }\end{array}$ \\
\hline 3 & $.854^{\mathrm{a}}$ & .681 & .634 & 1.87632 \\
\hline
\end{tabular}

a. Predictors: (Constant), Flipped learning

\section{Discussion}

The results of data analysis in this study show that flipped learning strategy successfully influences the students' learning motivation, attitudes, and engagement. Table 9 provides the summary of this study's findings as resulted in linear regression analysis using 24-version of IBM-SPSS. All three hypothesis statements formulated in this study were empirically confirmed. Hence, it is a worth saying that flipped learning strategy is a positive predictor for students' learning motivation, attitudes, and engagement to join in "Introduction to Educational Technology" course.

Table 9. Summary of the Findings

\begin{tabular}{llccc}
\hline Hypothesis & \multicolumn{1}{c}{ Path } & $\begin{array}{c}\text { P- } \\
\text { value }\end{array}$ & t-value & Result \\
\hline $\mathrm{H} 1$ & $\begin{array}{l}\text { Flipper learning strategy } \rightarrow \text { students' } \\
\text { learning motivation }\end{array}$ & .001 & 6.881 & Support \\
\hline $\mathrm{H} 2$ & $\begin{array}{l}\text { Flipper learning strategy } \rightarrow \text { students' } \\
\text { learning attitudes }\end{array}$ & .007 & 3.811 & Support \\
\hline $\mathrm{H} 3$ & $\begin{array}{l}\text { Flipper learning strategy } \rightarrow \text { students' } \\
\text { learning engagement }\end{array}$ & .003 & 4.345 & Support \\
\hline
\end{tabular}

The first finding of this study states that flipped learning strategy was affecting the students' learning motivation. It aligns with prior research findings about how the flipped learning approach enhances students' learning motivation, such as in (Chen et al., 2014; Davies et al., 2013; Makruf et al., 2021; Suprapti \& Nugroho, 2021; Yilmaz, 2017). The flipped learning environment offers students ample opportunities to move from traditional and teacher-centered teaching toward student-centered, collaborative learning, where students are motivated to actively be involved in the learning activities.

The second finding of this study stated that flipped learning had an effect on the students' learning attitudes. The students had positive attitudes about the practice of flipped learning strategy in their classrooms. This result agrees with the findings of Chao et al. (2015) and Lin and Chen (2016) that flipped learning could facilitate the efficacy of teaching-learning process and both teachers and students had a positive perception about flipping the classroom activities. The finding of Chao et al. (2015) even emphasized that students' learning attitudes, motivation, and self-evaluation were enhanced as flipped learning approach affects the students' transfer of learning.

The third finding of this study showed that there was a positive relationship between flipped learning strategy and students' learning engagement. This result is in accord with the findings of Bergmann and Sams (2012), Gilboy et al. (2015), and Saulnier (2015) which pointed out that the video-based flipped instruction not only enhanced the students' motivation, but also made them actively engaged in the learning activities, indicating that flipped learning approach was successful in achieving the classroom goals and objectives.

The findings of this study contribute to offering fruitful insights for teachers and school/college administrators in order to adapt to the current paradigm of 'modern' 
teaching and learning, where technology and students' learning freedom become the main attribute. With the results of this study, it is implied that designing technologybased teaching activities is a crucial part of teachers' role and responsibility (Nugroho et al., 2021). Our students nowadays are well-known as digital natives, so that learning activities based on technology are highly recommended (Mutiaraningrum \& Nugroho, 2020). Moreover, it was proven by this study's results where flipped learning method is a promising approach to enhance students' learning motivation, attitude, and engagement.

\section{Conclusion}

The present study explores effects of flipped learning strategy on undergraduate students' learning motivation, attitudes, and engagement. Three hypotheses were formulated in this study and were tested using linear regression by the assistance of 24version of IBM-SPSS. The results reveal that flipped learning strategy had a positive relationship with students' learning motivation ( $p$-value $.001<.05$ ), attitudes (p-value $.007<.05$ ), and engagement ( $\mathrm{p}$-value $.003<.05$ ). Thus, the empirical answers of the hypotheses statements are defined.

This study is limited in terms of analysis on potential reasons behind the positive relationship between flipped learning and students' motivation, attitudes, and engagement. Therefore, future studies are to explore an in-depth understanding about this issue using qualitative approach, so that it will provide clear description about the empirical relationship. Moreover, future studies can also investigate the relation between flipped learning with other variables such as students' learning autonomy, higher order thinking skills, and classroom achievements.

\section{References}

Bergmann, J., \& Sams, A. (2012). Flip your classroom: Reach every student in every class every day. International society for technology in education.

Chang, R.-C., Chung, L.-Y., \& Huang, Y.-M. (2016). Developing an interactive augmented reality system as a complement to plant education and comparing its effectiveness with video learning. Interactive Learning Environments, 24(6), 1245-1264. https://doi.org/10.1080/10494820.2014.982131

Chao, C., Chen, Y., \& Chuang, K. (2015). Exploring students' learning attitude and achievement in flipped learning supported computer aided design curriculum: A study in high school engineering education. Computer Applications in Engineering Education, 23(4), 514-526. https://doi.org/10.1002/cae.21622

Chen Hsieh, J. S., Wu, W.-C. V., \& Marek, M. W. (2017). Using the flipped classroom to enhance EFL learning. Computer Assisted Language Learning, 30(1), 1-21. https://doi.org/10.1080/09588221.2015.1111910

Chen, Y., Wang, Y., \& Chen, N.-S. (2014). Is FLIP enough? Or should we use the FLIPPED model instead? Computers \& Education, 79(October), 16-27. https://doi.org/10.1016/j.compedu.2014.07.004

Chung, E. J., \& Lee, B.-H. (2018). The effects of flipped learning on learning motivation and attitudes in a class of college physical therapy students. Journal of ProblemBased Learning, 5(1), 29-36.

Coley, K., Hantla, B., \& Cobb, C. (2013). Best practices for beginning a flipped classroom in the humanities. NAPCE Annual Conference, Rosemont, IL.

Davies, R. S., Dean, D. L., \& Ball, N. (2013). Flipping the classroom and instructional technology integration in a college-level information systems spreadsheet course. Educational Technology Research and Development, 61(4), 563-580. https://doi.org/10.1007/s11423-013-9305-6

Gilboy, M. B., Heinerichs, S., \& Pazzaglia, G. (2015). Enhancing student engagement using the flipped classroom. Journal of Nutrition Education and Behavior, 47(1), 109-

Mariam Haghegh, Arif Nugroho. Video-based flipped learning in higher education: Effects on students'

learning motivation, attitudes, and engagement 
114. https://doi.org/10.1016/j.jneb.2014.08.008

Ginola, D., \& Sidabalok, D. M. (2016). The Implementation of Flipped Classroom by Using Schoology in Speaking II Class of English Education Study Program of Teacher Training and Education Faculty of Bandar Lampung University. Proceding of International Conference on Education and Language (ICEL) (pp 199-207). Lampung Indonesia.

Haghighi, H., Jafarigohar, M., Khoshsima, H., \& Vahdany, F. (2019). Impact of flipped classroom on EFL learners' appropriate use of refusal: achievement, participation, perception. Computer Assisted Language Learning, 32(3), 261-293. https://doi.org/10.1080/09588221.2018.1504083

Heo, H. J., \& Chun, B. A. (2018). Improving the higher order thinking skills using flipped learning: Focused on the in-class activities with problem posing and solving. Asia Life Sciences Suplement, 15(4), 2187-2200.

Hinojo Lucena, F. J., Lopez Belmonte, J., Fuentes Cabrera, A., Trujillo Torres, J. M., \& Pozo Sanchez, S. (2020). Academic effects of the use of flipped learning in physical education. International Journal of Environmental Research and Public Health, 17(1), 276. https://doi.org/10.3390/ijerph17010276

Hung, H.-T. (2015). Flipping the classroom for English language learners to foster active learning. Computer Assisted Language Learning, 28(1), 81-96. https://doi.org/10.1080/09588221.2014.967701

Hwang, G.-J., Lai, C.-L., \& Wang, S.-Y. (2015). Seamless flipped learning: a mobile technology-enhanced flipped classroom with effective learning strategies. Journal of Computers in Education, 2(4), 449-473. https://doi.org/10.1007/s40692-0150043-0

Hwang, G. J., Yin, C., \& Chu, H. C. (2019). The era of flipped learning: promoting active learning and higher order thinking with innovative flipped learning strategies and supporting systems. Interactive Learning Environments, 27(8), 991-994. https://doi.org/10.1080/10494820.2019.1667150

Jamaludin, R., \& Osman, S. Z. M. (2014). The use of a flipped classroom to enhance engagement and promote active learning. Journal of Education and Practice, 5(2), 124-131.

Karaca, C., \& Ocak, M. A. (2017). Effects of Flipped Learning on University Students' Academic Achievement in Algorithms and Programming Education. International Online Journal of Educational Sciences, 9(2), 527-543.

Katchamat, P. (2018). The Effect of Flipped Classroom Instruction on Appropriacy of English Apology by Thai EFL Learners. International Journal of Pedagogy and Teacher Education, 2(Focus Issue July), 13-119. https://doi.org/10.20961/ijpte.v2i0.25142

Lai, C., \& Wu, C. (2006). Using handhelds in a Jigsaw cooperative learning environment. Journal of Computer Assisted Learning, 22(4), 284-297. https://doi.org/10.1111/j.1365-2729.2006.00176.x

Lee, G., \& Wallace, A. (2018). Flipped learning in the English as a foreign language classroom: Outcomes and perceptions. TESOL Quarterly, 52(1), 62-84. https://doi.org/10.1002/tesq.372

Lin, P.-C., \& Chen, H.-M. (2016). The effects of flipped classroom on learning effectiveness: using learning satisfaction as the mediator. World Transactions on Engineering and Technology Education, 14(2), 231-244.

Lo, C. K., \& Hew, K. F. (2020). A comparison of flipped learning with gamification, traditional learning, and online independent study: the effects on students' mathematics achievement and cognitive engagement. Interactive Learning Environments, 28(4), 464-481. https://doi.org/10.1080/10494820.2018.1541910

Makruf, I., Choiriyah, S., \& Nugroho, A. (2021). Flipped Learning and Communicative 
Competence: An Experimental Study of English Learners. International Journal of Education in Mathematics, Science and Technology, 9(4), 571-584. https://doi.org/10.46328/ijemst.1960

Mutiaraningrum, I., \& Nugroho, A. (2020). Social construction of knowledge in synchronous text-based discussion during English language learning. Journal on English as a Foreign Language, 10(2), 315-336. https://doi.org/10.23971/jefl.v10i2.1934

Nugroho, A., Haghegh, M., \& Triana, Y. (2021). Emergency Remote Teaching amidst Global Pandemic: Voices of Indonesian EFL Teachers. VELES Voices of English Language Education Society, 6(1), 66-80. https://doi.org/10.29408/veles\%20journal.v5i1.3258

Pierce, R., Fox, J., \& Dunn, B. J. (2012). Instructional design and assessment: Vodcasts and activelearning exercises in a "flipped classroom" model of a renal pharmacotherapy module. American Journal of Pharmaceutical Education, 76(10), $1-5$.

Saulnier, B. (2015). The flipped classroom in systems analysis \& design: Leveraging technology to increase student engagement. Information Systems Education Journal, 13(4), 33.

Singay, S. (2020). Flipped learning in the English as a second language classroom: Bhutanese students' perceptions and attitudes of flipped learning approach in learning grammar. Indonesian Journal of Applied Linguistics, 9(3), 666-674.

Strayer, J. F. (2012). How learning in an inverted classroom influences cooperation, innovation and task orientation. Learning Environments Research, 15(2), 171-193.

Suprapti, S., \& Nugroho, A. \& Putra, H. R. P. (2021). Flipped Learning Instruction to Enhance University Students' Higher Order Thinking Skills. Jurnal Kependidikan: Jurnal Hasil Penelitian Dan Kajian Kepustakaan Di Bidang Pendidikan, Pengajaran Dan Pembelajaran, 7(2), 261-269. https://doi.org/10.33394/jk.v7i2.3320

Wahyuningsih, E., \& Baidi, B. (2021). Scrutinizing the potential use of Discord application as a digital platform amidst emergency remote learning. Journal of Educational Management and Instruction (JEMIN), 1(1), 9-18. https://doi.org/10.22515/jemin.v1i1.3448

Webb, M., \& Doman, E. (2020). Impacts of flipped classrooms on learner attitudes towards technology-enhanced language learning. Computer Assisted Language Learning, 33(3), 240-274. https://doi.org/10.1080/09588221.2018.1557692

Wei, C.-W., Lin, Y.-C., \& Lin, Y.-T. (2016). An interactive diagnosis approach for supporting clinical nursing courses. Interactive Learning Environments, 24(8), 1795-1811.

Yilmaz, R. (2017). Exploring the role of e-learning readiness on student satisfaction and motivation in flipped classroom. Computers in Human Behavior, 70, 251-260.

Young, T. P., Bailey, C. J., Guptill, M., Thorp, A. W., \& Thomas, T. L. (2014). The flipped classroom: a modality for mixed asynchronous and synchronous learning in a residency program. Western Journal of Emergency Medicine, 15(7), 938-934. http://doi.org. 10.5811/westjem.2014.10.23515

Zhang, S., Wang, Z., Chang, R., Wang, H., Xu, C., Yu, X., Tsamlag, L., Dong, Y., Wang, H., \& Cai, Y. (2020). COVID-19 containment: China provides important lessons for global response. Frontiers of Medicine, 1-5. 